Journal of Social Sciences 6 (4): 532-536, 2010

ISSN 1549-3652

(C) 2010 Science Publications

\title{
Cyberbullying Education for Parents: A Guide for Clinicians
}

\author{
Margaret Hannah \\ Freedman Center for Child and Family Development, \\ The Massachusetts School of Professional Psychology, \\ West Roxbury, Massachusetts, USA
}

\begin{abstract}
Cyberbullying is a problem that is growing rapidly, current estimates indicate that at least $20-35 \%$ of children and adolescents experience cyberbullying. Clinicians need to be equipped with a framework to help parents in the role they play with their children and the cyberworld. This paper will guide professionals as they advise parents in navigating the world of cyberbullying. It is based on research on parenting, child development and cyberbullying. Parents today typically feel ill-equipped to respond to cyberbullying. They may be convinced that they were born a generation too late to relate to current online etiquette or to know what behaviors are appropriate. Many teens, as they try to separate themselves from authority figures, make it their mission to keep their online world-with all its positive and frightening attributes-"their own". While bullying has now taken on a new dimension, the behavior itself is ancient. Parents should not feel powerless; instead, they should feel confident about responding in ways that are familiar and in concert with their own well-established parenting values and style. As challenging as it is to guide parents today around electronic issues such as cyberbullying, three basic principles can help guide you in your conversations with the parents you are seeking to educate. Remind parents to rely upon the basic strategies they successfully employ on a day-to-day basis: NURTURE children, provide STRUCTURE that is developmentally sound and JOIN children in their world in appropriate ways. This article provides details on how to help parents successfully achieve these three goals.
\end{abstract}

Key words: Cyberbullying, parenting, clinicians, NURTURE children

\section{INTRODUCTION}

Despite their pivotal role in it, parents today typically feel ill-equipped to respond to cyberbullying. Clinicians who might offer them guidance often feel similarly. A 2009 survey (Netsmartz411, 2010) indicated that $84 \%$ of parents do not know how to respond to cyberbullying. Because they didn't grow up in the online world, parents may be unfamiliar with certain technologies and "cyberspeak". They may be convinced that they were born a generation too late to relate to current online etiquette or to know what behaviors are appropriate. Even if parents are internet savvy, they may be astounded by how easily young children adopt and adapt each new advance in technology.

As a professional interacting with (and possibly educating) parents, you may also be dealing with the biggest roadblock to feelings of parental competency: the adolescent. Many teens, as they try to separate themselves from authority figures, make it their mission to keep their online world-with all its positive and frightening attributes-"their own". In doing so, they faithfully follow in the footsteps of myriad teens before them who posted DO NOT ENTER signs on their bedroom doors, spent hours whispering to friends on the phone and wrote their journal entries in code.

That knowledge should help today's parents take heart. Because while bullying has now taken on a new dimension, the behavior itself is ancient. Parents should not feel powerless; instead, they should feel confident about responding in ways that are familiar and in concert with their own well-established parenting values and style.

As challenging as it is to study with parents today around electronic issues such as cyberbullying, three basic principles can help guide you in your conversations with the parents you are seeking to educate. Remind parents to rely upon the basic strategies they successfully employ on a day-to-day basis: NURTURE children, provide STRUCTURE that is developmentally sound and JOIN children in their world in appropriate ways.

The purpose of this study is to guide professionals as they advise parents in navigating the world of cyberbullying and their role. It is based on research on parenting, child development and cyberbullying. 
Nurture children: Before we can nurture children (and parents) around the issue of cyberbullying, we must first know how to recognize it.

Cyberbullying is defined as a word, action, or other electronic communication or behavior that is:

- Aggressive, cruel and/or threatening

- Repetitive

- Characterized as an imbalance of physical, psychological and/or emotional power. The power advantage may be due to social status, age, size, ability and/or popularity

- Anonymous (Englander et al., 2009)

Note that except for the addition of the word "electronic", the definition could be describing bullying we have all witnessed, experienced, or perpetrated. By focusing on the familiar, we can empower parents to confront bullying in its newest form. There are some elements of cyberbullying that are in common with bullying, such its need to be hidden from adults; while other elements are completely different, for example, cyberbullying often draws in a larger and separate group of children (Englander et al., 2009)

This means that children who normally would never bully might try cyberbullying.

Helping parents to NURTURE their children requires asking them some of the following questions:

- If you do not want your child to be aggressive, cruel, or threatening in the off-line world, what do you do? Or, if your child is experiencing threats or cruelty from others in the off-line world, how do you respond?

- Is this behavior or privilege developmentally appropriate? For instance, a four-year old may hit other children just to experiment with reactions and responses and an eleven-year old may laugh when another child is ridiculed While parents may not like these behaviors, they are developmentally appropriate and they do provide teaching opportunities. Remind parents that nurturing requires thinking about the age of their child

- Does your child repeat such actions without remorse? Or is he/she consistently on the receiving end of such abuse? In either case, it is time for you to step in with appropriate measures, such as redirection, modeling expected behavior, discussion, positive discipline and/or consequences and possibly talking with school or community officials

- Do you have open doors for communication with your child by being non-judgmental when they come to you for assistance, when he/she runs into trouble?

Sometimes there is a question of cyberbullying (and current estimates indicate that at least 20-35\% of children and adolescents experience cyberbullying (Kowalski and Limber, 2007; Diamanduros et al., 2008; Sumalatha and Ramakrishnaiah, 2004)-possibly many more). Whether a child is a potential victim or bully (or witness/bystander), parents need to remind him/her about family values regarding friendship and respect for self and others; these values apply whether you are dealing with in-person or online relationships. Helping children to have successful, safe online relationships and offering guidance and appropriate oversight, is a safety net that can prevent or mitigate cyberbullying. In other words, provide structure.

Provide structure: In order to provide meaningful structure, a parent must become familiar with the online world of children.

Ask the parent the following questions:

- How much time does your child spend on the computer?

- Do you know her favorite sites?

- Does your child have a Facebook or MySpace page? What's in his profile? Who are his online friends?

- Is our home computer kept in a central, high-traffic area?

- Are you (or another adult) aware and nearby when your child uses the computer? (Not surprisingly, research indicates that bullying, online or off, is not likely to occur in adult presence)

Parents should ask their children:

- What do you like about the internet world?

- What do you do online?

- What do your friends like to do online?

Just as a parent may ask a child about her school day or attend her basketball game, showing friendly interest in online activity is quite similar and appropriate.

Coach parents that once they begin to feel educated about their child's internet use, they need to decide what structures can be put into place that reflect and reinforce family values using the same familiar criteria one uses to set a child's "real world" privileges and limits, such as age, relative maturity, problem-solving 
skills, reliability and so on. A parent must weigh his child's desire to use the computer versus legitimate need (homework, reasonable peer networking). When applying structure parents will need to take into account the developmental changes that may affect a child's online use: A six-year old may not "push the envelope" while exploring the basic internet features of a cell phone or the family computer, but an eleven-year old may not be able to resist the lure of off-limit sites. An independent high school student, who maintains good grades and is working to save money for college, may understandably resist any parental attempt to oversee internet use, while the parent, understandably, will want to keep her safe. A parent needs to be ready and willing to reevaluate limits and privileges in response to growth and appropriate and inappropriate behaviors.

As one might with off-line limit setting, asking the child what he thinks are reasonable limits often will help build structures that will have better success. One may not always follow the advice given by the child, but allowing him to participate in limit setting often opens lines of communication. Despite protestations, children of all ages need and want to feel safe and protected and they depend on parents or trusted adults to provide structure and a web of safety.

Reminding children that although internet use seems ordinary and expected to them, the online world is actually still young and evolving. Where parents once taught their children "not to put anything in writing you may regret", today's children must understand that anything posted on the internet can live forever, in ever new and misrepresented forms. Personal information and photos intended to be shared only with one's closest friends can quickly be passed around the world. Natural consequences of a child's internet carelessness or naïveté could be strangers on her Facebook page and danger at her door. Therefore, parental limits and consequences must be clear and firm.

Parents can get help with that enforcement by letting other caregivers, family members, parents of children's friends and teachers know the limits that have been set for online behavior and check on compliance.

Parents should expect that even the best limit setting and structures will be tested. A parent may need to intervene when necessary without overreacting. We want parents to be able to keep the lines of communication open so parent and child can navigate the online world and combat cyberbullying together.

Join children in the internet world: In order to nurture and guide a child, it is important for parents to become part of his or her world. When we want to be sure to have a toddler's attention, we kneel down to her level. To know what she's interested in and how she's developing, we don't just observe her from afar; we get down on the floor and play with her and spend time with her. In the same way, if we approach older children at their level we'll improve our communication and increase our knowledge of them. So how can a parent become a participant in a child's online world?

Some simple "joining steps":

- Does your child have a Facebook page? If so, then you should have one, too. Learn how to use it and "friend" your child

- Check out MySpace.com if this is a site your child or his friends use. In either case, don't abuse these golden opportunities to be part of his world. If you scrutinize every aspect of his page and comment on his "conversations" with his friends, he will quickly shut you out

- Choose your battles wisely and intervene only when necessary-just as you would in the off-line world. Remember, not every indiscretion is potentially life-altering; let your child be a child. Respect his privacy, unless he gives you reason to reevaluate

- If your child is a fan of a particular TV show, like American Idol, ask her if she visits any official or fan-run web sites. Take a look to see what sort of conversations, language and photos, may be posted there. This is a great opportunity to engage her in conversation about her favorite artists and music styles and to talk about how fans can share views in appropriate, non-offensive ways

- A parent may also introduce a child to sites they like, or sites that have family-friendly or educational games. Perhaps both like the books of a particular author and they can check out the web site together. Parent choices will remind him of personal values

There are many monitoring programs one can be installed on a computer, which can help depersonalize potentially charged situations of inappropriate internet use. Deciding if this is an appropriate strategy for the family computer is often helpful; however a monitoring device will not take the place of parenting. Monitors alone cannot keep children safe, or prevent bullying behaviors.

Don't be afraid to help parents do a little investigating if they suspect that their child is getting in over his head or is involved in bullying. Invite parents to learn and recognize the email addresses and screen 
names of their child's "real world" friends and keep an eye out for unusual or unfamiliar names. One can Google the names of people who unfamiliar to learn more about them. Checking the computer's history to see what sites are visited often is often a helpful technique and monitoring excessive or unexpected phone charges can provide important information for conversations with children.

Remind parents that they do not have to sort out this strange, new, ever-changing world without help; old-fashioned networking is still a reliable resource. Reinforce asking other parents how they stay connected with their children's online lives. Help parents draw on each others' experiences and brainstorm ideas for dealing with safety issues. Attending a community seminar on children's online use, safety and cyberbullying and establishing a partnership with the school in designing policy and procedure and reinforcing anti-bullying is an empowering strategy for many parents.

Perhaps most importantly, a parent can be an active participant in a child's online life by paying close attention to her off-line life (Englander, 2010). Teach parents to watch for changes in behavior that may be symptoms of a problem in either world. Parents should be encouraged to ask teachers, coaches and other adults who know their child well to let them know if they notice any odd or worrisome developments.

The following questions may help a parent be aware of behaviors or behavioral changes that may indicate trouble online or off, including bullying:

- Does your child spend too many hours on the computer?

- Does she seem to shy away from all computer use?

- Does he close the computer screen when you enter the room or come near? (Keep a log of how often this happens. It is good to have details and facts when you engage in conversations about concerns)

- Is she secretive about internet activities?

- Is he expressing body aches or pains or visiting the school nurse more often?

- Is she dressing in a manner that is unfamiliar to you?

- Is he acting out aggression at home?

- Does she cry more?

- Have you noticed changes in his eating and/or sleeping behaviors?

- Does she not want to go out of the house as much as usual?

- Does he go out with new friends he won't bring home for you to meet?

- Has she lost interest in longtime friends or hobbies?
- Have his grades slipped?

If a parent notices any of these-or other-troubling behaviors, engage the parent in conversations about the observations. Let parents know that you are always available to listen and that you are there to help, she doesn't have to face it or solve it alone. Parents may need you to encourage them to contact outside resources: School, other adults in the community and even the police.

Since people first became parents, each new generation of mothers and fathers has had to learn to guide their children through the new and unknown and that holds true today. But what also holds true are the time-tested parenting skills of nurturing, providing structure and joining children in appropriate ways. Parents often need permission to turn and return to these skills as they help their child navigate the many incredible worlds that are his or hers to explore.

Sidebar: Back to the Basics...Principals that Help Prevent Cyberbullying:

- Know your child and watch for warning signs of cyberbullying

- Reinforce family values around being a friend and respect for all individuals regardless of differences

- Set limits for computer use and be consistent

- Get educated about the cyberworld and continue to learn more. The online world is changing rapidly and it is important to keep abreast of changes and the implications for parenting and preventing cyberbullying

- Talk with your child about online use. Listen to your child and your child's friends about current trends for online use

- Establish a partnership with the school about cyberbullying. Learn the school policies and become an active participant in reinforcing and designing cyberbullying programs

- Teach your child to how to report cyberbullying to trusted adults

- NURTURE your child and your relationship; Provide STRUCTURE for internet use that is developmentally appropriate; JOIN your child and the community to prevent CYBERBULLYING

\section{CONCLUSION}

Although parents today often feel helpless in the face of rapidly evolving technology, many of principles of raising children in the digital age remain the same as 
they were a generation ago. Professionals who help parents cope with parenting children today can emphasize that parents need to use the skills they have used since time immemorial: nurture and connect with your child; provide structure for your child's activities and join your child in their learning adventure online, learning as they do. By applying these skills to children they are raising today, parents can help children become model citizens of cyberspace, as well as model citizens of society in general.

\section{REFERENCES}

Diamanduros, T., E. Downs and S.J. Jenkins, 2008. The role of school psychologists in the assessment, preventions and intervention of cyber bullying. Psychol. Schools, 45: 693-704. DOI: 10.1002/pits.20335
Englander, E., 2010. The online life of children. Proceeding of the Newton Partnership Workshop, Mar. 20-20, Commonwealth of Massachusetts, Newton, MA., pp: 1-1.

Englander, E., E. Mills and M. McCoy, 2009. Cyberbullying and information exposure: Usergenerated content in post-secondary education. Int. J. Contemp. Sociol., 46: 215-230. http://cat.inist.fr/?aModele $=$ afficheN\&cpsidt=22348942

Kowalski, R.M. and S.P. Limber, 2007. Electronic bullying among middle school students. J. Adolesc. Health, 41: S22-S30. PMID: 18047942

Netsmartz411, 2010. Net cetera: Chatting with kids about being online. ResourceShelf. http://web.resourceshelf.com/go/resourceblog/58682

Sumalatha, K. and D. Ramakrishnaiah, 2004. Sex bias in secondary school social studies textbooks: A case study in India. Am. J. Applied Sci., 1: 62-63. DOI: $10.3844 / .2004 .62 .63$ 